\title{
The Loyalty Trap: Regime Ethnic Exclusion, Commitment Problems, and Civil War Duration in Syria and Beyond
}

Theodore McLauchlin, Université de Montréal

Security Studies 27, no. 2 (2018) : 296-317

This article examines the impact of the ethnic exclusiveness of regimes on commitment problems and hence on civil conflict duration. It argues that members of privileged in-groups in highly exclusive regimes can be trapped into compliance with the regime. Ethnic exclusion helps to construct privileged-group members as regime loyalists. They therefore fear rebel reprisals even if they surrender or defect, and hence persist in fighting. The article finds in particular that privileged-group members mistrust even rebels who mobilize on a non-ethnic agenda. Severe ethnic exclusion induces members of privileged groups to regard rebel reassurances, including non-ethnic aims, as suspect. Exclusion therefore induces privileged-group cohesion, an effect more resistant to rebel reassurances than previously recognized. A case study of the Syrian civil war shows this dynamic at a micro level, and a cross-national statistical analysis gives partial evidence that it lengthens civil conflicts on a large scale.

This article examines whether, and how, ethnic politics makes civil conflicts long and intractable. ${ }^{1}$ It studies the impact of regime ethnic ${ }^{2}$ exclusiveness on credible commitments and hence on civil war duration. It argues that ethnic exclusion by the regime undermines the trust in rebel reassurances that members of privileged groups might have. Ethnic exclusion puts privileged groups in a loyalty trap: while some privileged-group members enjoy greater access to

\footnotetext{
${ }^{1}$ For discussion, advice, and feedback, I sincerely thank Frédérick Bastien, Laurie Beaudonnet, André Blais, Kanisha Bond, Paul Johnson, Christopher Phillips, Marie-Eve Reny, Ora Szekely, Simon Thibault, Marie-Joëlle Zahar, conference participants at the annual meeting of the International Studies Association, the editors of Security Studies, and two anonymous reviewers. My gratitude is due above all to Vincent Arel-Bundock, Kevin Mazur, Sarah Parkinson, and Lee Seymour. Remaining mistakes are entirely my own.

${ }^{2}$ In this article I follow disciplinary practice in referring to as-if ascriptive identity claims as "ethnic", hence including linguistic, religious, and racial claims. See Kanchan Chandra, "What Is Ethnic Identity and Does It Matter?," Annual Review of Political Science 9 (2006): 397-424.
} 
power than others, all are identified by their ethnic identity as regime loyalists. Hence, they fear that they will be mistrusted and persecuted by rebels even if they surrender, defect or otherwise cooperate, and so will fight on. Recent studies of civil war severity and duration have made this argument as well, ${ }^{3}$ but they leave open a critical question: can rebels overcome this loyalty trap through reassurances to privileged-group members, for example by mobilizing for non-ethnic agendas? If they can, the loyalty trap problem can be mitigated, in principle.

I show that rebels cannot fully overcome the mistrust that characterizes exclusive regimes by mobilizing along non-ethnic lines, seeking to transcend ethnic exclusion. While making nonethnic appeals may help rebels make credible reassurances to a certain extent, regime exclusiveness greatly limits this effect. The more exclusive the regime, the more members of privileged in-groups find rebel reassurances unconvincing. In other words, through exclusion, a regime can unilaterally weaken the credibility of its own adversary. The result is that, with rebel groups making non-ethnic appeals, civil wars are longer the more exclusive the regime. Nonethnic rebel appeals still do lead to shorter civil wars than mobilizing excluded groups, but the regime side's own exclusion policy erodes the difference: non-ethnic rebellions can have civil wars that are just as long as rebels mobilizing excluded groups, provided the regime is sufficiently exclusive. There are twin tragic ironies here. Members of the in-group find it difficult to abandon the regime from which they (supposedly) benefit, keeping them in costly conflicts. And the very exclusion rebels seek to change undermines their credibility.

I find evidence for one silver lining: the general effect of exclusion may be mitigated to some extent when the excluded population is diverse. I suggest that this is because, when there

\footnotetext{
${ }^{3}$ Lindsay Heger and Idean Salehyan, "Ruthless Rulers: Coalition Size and the Severity of Civil Conflict," International Studies Quarterly 51, no. 2 (2007): 389; Julian Wucherpfennig et al., "Ethnicity, the State, and the Duration of Civil War," World Politics 64, no. 1 (2012): 86.
} 
are many out-groups, a rebel group has stronger incentives to hold to non-ethnic appeals to mobilize around a common program, and so those appeals are more credible.

The article first demonstrates the plausibility of this loyalty trap in an analysis of the Syrian civil war. The primary rebel umbrella group at the outset of the war, the Free Syrian Army, at first avoided explicit identity claims in its official discourse, instead presenting itself as a broad-based pro-democracy movement against the brutally repressive, authoritarian and exclusive Assad regime. But some members of the Alawite minority dominate the regime, and the regime was and is popularly identified as Alawite. It was therefore difficult for any Alawite to believe pluralist opposition claims, and hence to believe that they would not be targets for revenge. The subsequent emergence of more sectarian Sunni rebel groups has reinforced this suspicion.

The Syrian case indicates that regime exclusiveness makes it difficult for rebels to credibly propound a non-ethnic agenda and obtain cooperation among members of privileged groups. I further analyze whether these commitment problems emerging from exclusion apply beyond Syria and lead to longer civil wars. I find partial evidence that they do. Consistent with the loyalty trap, I find that even in conflicts where rebels do not make ethnic claims, regime exclusiveness, and especially excluding a few large groups, makes wars longer. However, I also find evidence that other mechanisms beyond the loyalty trap may help explain this finding.

The article builds on and extends past work developing the commitment-problem approach to the identity dynamics of civil conflicts. ${ }^{4}$ This past work argues that civil conflicts are long and bloody when one side fears punishment along ethnic lines, and it identifies regime

\footnotetext{
${ }^{4}$ James D. Fearon, "Why Do Some Civil Wars Last So Much Longer than Others?," Journal of Peace Research 41, no. 3 (2004): 275-301; Heger and Salehyan, "Ruthless Rulers"; Wucherpfennig et al., "Ethnicity, the State."
} 
exclusion as a source of this fear. Wucherpfennig and colleagues argue that "because exclusion generates feelings of resentment and fosters radicalism, it raises the costs [to members of a privileged group] of turning the tables...This commitment problem is likely to be particularly severe under minority rule,"5 and Heger and Salehyan argue that "members of the old regime may face purges, resulting in death or exile...when they form a small faction winning coalitions are easily targeted victims of persecution in the event of an overthrow.",

This article, however, draws out an important and previously unexplored implication of this commitment-problem approach: ethnic exclusion by the regime undermines the credibility of even non-ethnic rebel appeals, and hence makes civil conflicts longer even when rebels do not make ethnic claims. Wucherpfennig and colleagues test the impact of regime ethnic exclusion via rebel claims, arguing that exclusion along ethnic lines "makes it difficult for both for rebel groups fighting on behalf of excluded ethnic groups and for incumbent governments to reach settlements that would allow for effective conflict resolution, thus leading to protracted conflicts, ${ }^{\prime 7}$ and finding that civil wars are longer if rebels mobilize politically excluded ethnic groups. ${ }^{8}$ I argue that the logic applies even to rebel groups that do not mobilize along ethnic lines, because regime exclusion undermines the reassurances that these non-ethnic claims might offer to members of privileged groups. Hence, lest one conclude that rebels can override the problems Wucherpfennig and colleagues highlight by propounding nonethnic agendas, I show that regime exclusion by itself makes these nonethnic claims less credible and lengthens civil wars. The argument is therefore similar to Heger and Salehyan's finding that minority rule presages especially violent civil conflicts, since their empirical finding is about the regime and

\footnotetext{
${ }^{5}$ Wucherpfennig et al., "Ethnicity, the State," 86.

${ }^{6}$ Heger and Salehyan, "Ruthless Rulers," 389.

7 Wucherpfennig et al., "Ethnicity, the State," 87. My emphasis.

${ }^{8}$ Ibid., 100-101.
} 
not about rebel characteristics. ${ }^{9}$ I apply a similar analysis to civil conflict duration, and go further by breaking the result down by rebel claims, showing that exclusion lengthens civil conflicts even for non-ethnic rebels.

However, I also highlight an important distinction on the regime side, between the concentrated benefits members of a narrow regime receive, and fear of reprisals. Heger and Salehyan refer to both factors to explain why members of ethnically exclusive regimes are especially motivated to fight, but the former explanation plays an especially central role in their argument. The smaller the governing coalition, the more each member of the coalition gets out of it, and the worse the loss would be from defeat or compromise. ${ }^{10}$ The fear of reprisal is a different mechanism with different observable implications. It suggests that not all narrow ruling coalitions are created equal: when an identity group is associated with the regime, its members may fear reprisal all the more. And it suggests that people may fight for a regime from which they do not especially profit, as long as they fear they are identified with it.

Hence regime exclusion, by itself, has effects on civil conflict duration even if rebels seek to transcend it. The consequences are significant. The finding suggests that the compliance that ethnic preference policies encourage is more resistant than previously recognized to one side's efforts to transcend polarization. Rebels seeking to replace an ethnically exclusive regime with a nonethnic agenda will find it difficult to sell that agenda, because of exclusion itself. In turn, the result clarifies the incentives for ethnic identity politics on both sides. For regimes, ethnic exclusion does not just keep members of the in-group compliant against rebels who mobilize outgroup; it gives them an ethnic frame to reinterpret even explicitly non-ethnic rebellions. For rebel groups, the result shows that, while there may be some benefit to be gained from mobilizing

\footnotetext{
${ }^{9}$ Heger and Salehyan, "Ruthless Rulers."

${ }^{10}$ Ibid., 386.
} 
along non-ethnic lines, this benefit is greatly weakened in highly exclusive regimes, and the relative benefits of ethnic mobilization are clearer.

By showing that ethnically exclusive regimes experience longer civil wars even when rebels make nonethnic claims, I make three broader theoretical contributions. First, the article shows the need to pay more attention to the direct effect of the government side on identity dimensions of civil conflict. Standard definitions of "ethnic conflict" focus on the rebel side, even if they see regime policies as crucial elements of the background of ethnic conflicts. Data projects tend to code a whole conflict as "ethnic" if the rebel group involved explicitly claims to be acting on behalf of an ethnic group and recruits among that ethnic group; ${ }^{11}$ these studies attempt to identify systematic differences between this "type" of conflict and others. Even scholars who call into question the concept of "ethnic conflict" also focus on the rebel side. Kalyvas' important article highlighting the scale of ethnic defection - that is, of people fighting against armed groups claiming to represent their ethnic group - deals above all with defection from rebels to government. ${ }^{12}$ In contrast, I argue that it is often regimes that put ethnic politics front and center in civil wars. They can make ethnic markers relevant directly, not just by provoking ethnic rebellion but by setting up an ethnic frame to interpret rebellions. It can be the rebel side that seeks to de-ethnicize politics, and the regime side that pushes an ethnic frame. I find that highly exclusive regimes are often successful in doing so in spite of rebels' efforts.

Second, the article develops empirical implications of a constructivist and institutionalist perspective on the role of ethnic identity on loyalty in conflict. Some scholars claim that ethnic

\footnotetext{
${ }^{11}$ Nicholas Sambanis, "Do Ethnic and Nonethnic Civil Wars Have the Same Causes?: A Theoretical and Empirical Inquiry (Part 1)," Journal of Conflict Resolution 45, no. 3 (2001): 259-82; Wucherpfennig et al., "Ethnicity, the State."

${ }^{12}$ Stathis N. Kalyvas, "Ethnic Defection in Civil War," Comparative Political Studies 41, no. 8 (2008): 104368.
} 
ties are a powerful, straightforward predictor of people's loyalties in ethnic civil wars, making it difficult either to convince a losing side to surrender or to build a cross-ethnic coalition to support a peace agreement. ${ }^{13}$ However, others find that apparently "ethnic" conflicts involve many people who fight for the "wrong" side. ${ }^{14}$ Identity claims often emerge as ad-hoc justifications for coalitions that occur for other reasons, notably as actors seek survival and power. ${ }^{15}$ One might build on this skepticism to assert that identity claims are just epiphenomenal, so they do not really help understand which sides people support in civil conflicts. Another tack, which I follow, is to examine when and why identity boundaries are socially constructed as good predictors of people's decisions to support one side or another. ${ }^{16}$ This approach is thus constructivist, arguing that the use of identity as a marker of loyalty is a social fact; it is not automatic but emerges as a consequence of the actions and discourses of various political actors. The account is also institutionalist, focusing in particular on the role of policies that limit access to political power. Specifically, I examine how ethnic preference policies create stable expectations of compliance along identity lines. I argue that systematically favoring one group often identifies that group with the regime. This makes it difficult for members of that group to cooperate with rebels, mistrusting even the latter's nonethnic claims.

Finally, this article theorizes the link between individuals' compliance with a regime and the duration of civil conflict. Scholars frequently argue that wars last long when the sides cannot

\footnotetext{
${ }^{13}$ Chaim Kaufmann, "Intervention in Ethnic and Ideological Civil Wars: Why One Can Be Done and the Other Can’t," Security Studies 6, no. 1 (1996): 62-101.

${ }^{14}$ Kalyvas, "Ethnic Defection."

15 John Mueller, "The Banality of 'Ethnic War," International Security 25, no. 1 (2000): 42-70; Fotini Christia, Alliance Formation in Civil Wars (Cambridge: Cambridge University Press, 2012).

${ }^{16}$ Stathis N. Kalyvas and Matthew Adam Kocher, "Ethnic Cleavages and Irregular War: Iraq and Vietnam," Politics \& Society 35, no. 2 (2007): 213-14; Kanchan Chandra and Steven I. Wilkinson, "Measuring the Effect of 'Ethnicity," Comparative Political Studies 41, no. 4-5 (2008): 515-63.
} 
credibly commit to a settlement. ${ }^{17}$ I relax the assumption of unitary actors that underlies this approach $^{18}$ and expand past the commitment problems facing leaders that have received some attention. ${ }^{19}$ A war can end if followers decide to lay down arms or turn those arms around. Surrender, desertion, and defection are important mechanisms by which wars-especially civil conflicts - end. ${ }^{20}$ Any factor that prevents these actions can therefore lengthen civil wars. Hence, this article develops a followers' commitment problem: the inability to credibly commit to good treatment if an adversary's follower defects or surrenders can lengthen a civil conflict. Moreover, going beyond past work showing the importance of credible promises of good treatment for inducing defection and surrender, ${ }^{21}$ it shows that one party to a conflict can lack credibility not because of its own characteristics or actions, but in fact because of its adversary's. Specifically, by pursuing ethnic exclusion, a regime can make rebels less trustworthy. This has important implications: it means that, in the face of an adversary's strategies, there is only so much one can do to prove one's own trustworthiness.

\section{Ethnically exclusive regimes and civil wars}

My argument posits that ethnic identification is often a crucial element in a strategic calculus in which actors care mainly about survival, not about their "ethnic group's interests," which I do not take as given. I take seriously the question posed by Kalyvas, among others: to

\footnotetext{
${ }^{17}$ Barbara F. Walter, "The Critical Barrier to Civil War Settlement," International Organization 51, no. 3 (1997): 335-64; Fearon, "Why Do Some Civil Wars"; Alex Weisiger, Logics of War: Explanations for Limited and Unlimited Conflicts (Ithaca: Cornell University Press, 2013).

18 James D. Fearon, "Rationalist Explanations for War," International Organization 49, no. 3 (1995): $379-414$.

${ }^{19}$ Hein E. Goemans, War and Punishment: The Causes of War Termination and the First World War (Princeton: Princeton University Press, 2000).

${ }^{20}$ D.E.H. Russell, Rebellion, Revolution, and Armed Force (New York: Academic Press, 1974); Ben Connable and Martin C. Libicki, How Insurgencies End (Santa Monica, CA: Rand Corporation, 2010).

${ }^{21}$ Ryan Grauer, "Why Do Soldiers Give Up? A Self-Preservation Theory of Surrender," Security Studies 23, no. 3 (2014): 622-55.
} 
show how ethnic identity might make a difference to individual strategic choice in civil conflicts, not just to assume that the analyst can treat ethnic groups as cohesive actors. ${ }^{22}$ Ethnic identity matters to the degree that political actors and institutions make use of identity labels to classify individuals and to promote some at the expense of others. ${ }^{23}$

I argue that systematically excluding large numbers of people from political power on the basis of ethnic identity generates greater compliance with the regime among members of favored groups during civil conflicts. It does so through two main impacts on political life more broadly that carry on into wartime. First, exclusion identifies privileged-group members as regime loyalists. In everyday ethnic politics, exclusionary policies construct members of privileged groups as probable beneficiaries_and hence likely supporters - of the regime. Eventually, identity becomes a convenient information shortcut. ${ }^{24}$ Rather than needing to know whether someone actually gets a large share of benefits from the regime, one can simply use their identity markers, treating the regime as an ethnocracy, and hence treating members of privileged categories as all members of the regime. ${ }^{25}$ In civil conflicts especially, this process of labelling can serve as the basis for targeting people for "categorical" violence. ${ }^{26}$ Privileged-group members are likely to be highly aware of the possibility of being identified as regime loyalists.

The second effect is indirect, through political actors and their strategies: ethnic exclusion permits both government and opposition politicians to reinforce ethnic frames in their political

\footnotetext{
${ }^{22}$ Kalyvas, "Ethnic Defection."

${ }^{23}$ Chandra and Wilkinson, "Measuring the Effect of "Ethnicity.",

${ }^{24}$ Kanchan Chandra, Why Ethnic Parties Succeed: Patronage and Ethnic Head Counts in India (Cambridge: Cambridge University Press, 2004); Francesco Caselli and Wilbur John Coleman, "On the Theory of Ethnic Conflict," NBER Working Paper (Cambridge, MA: National Bureau of Economic Research, 2006).

25 Jeff Goodwin, “A Theory of Categorical Terrorism," Social Forces 84, no. 4 (2006): 2037.

${ }^{26}$ Goodwin, "A Theory of Categorical Terrorism"; Stathis N. Kalyvas, The Logic of Violence in Civil War (Cambridge: Cambridge University Press, 2006), 148-49; Hanne Fjelde and Lisa Hultman, "Weakening the Enemy: A Disaggregated Study of Violence against Civilians in Africa,” Journal of Conflict Resolution 58, no. 7 (2014): 1230-57.
} 
action. In the background to civil conflict, ethnic exclusion encourages political opposition groups to present grievances and demands along identity lines. This identity-based mobilization tends to make an identity frame for understanding politics even more salient among privilegedgroup members. It reinforces their sense of being identified with the regime. However, exclusion also provides fertile terrain for manipulation by state elites. By actively reminding in-group members of the possibility of mobilization on behalf of excluded groups, for example through spreading rumors of categorical violence, state elites and their agents can relatively easily reinforce pre-existing fears.

When mounting a rebellion against a highly exclusive regime, rebel groups typically propound ethnic agendas. ${ }^{27}$ But, crucially, not all do, even if opposition politicians have long made identity claims. Many, perhaps recognizing the mistrust that an ethnic agenda would prompt, might try to adopt a non-ethnic platform. Using the Wucherpfennig et al data on rebel group linkages to ethnic groups ${ }^{28}$ in the most exclusive quartile of regimes, 49 rebellions mobilize excluded groups, but 38 do not engage in ethnic mobilization (see Table 1 below). But the identification of in-group members as loyalists, coupled with a background of political mobilization on identity lines in the leadup to war, will tend to reinforce the fears of in-group members that rebels represent a threat to their safety because of their identity. With a background sense that they are identified with the regime, privileged-group members will fear revenge if the regime falls. They will be inclined to interpret the killing of civilians as categorical violence, even if it is not. And they may be particularly susceptible to elite reminders, such as rumors of categorical violence, planned or executed. Moreover, longstanding incentives for opposition to

\footnotetext{
${ }^{27}$ Andreas Wimmer, Lars-Erik Cederman, and Brian Min, "Ethnic Politics and Armed Conflict: A Configurational Analysis of a New Global Data Set," American Sociological Review 74, no. 2 (2009): $316-37$.

${ }^{28}$ Wucherpfennig et al., "Ethnicity, the State." This analysis even includes some modifications to recode some "non-ethnic" rebellions as acting for excluded groups; see the online appendix.
} 
mobilize along ethnic lines will persist. Privileged-group members will thus fear that even if a rebel group uses pluralist language now, it need not in the future. Pluralists might be outbid by rebel leaders more willing to push the interests of excluded groups.

Thus systematic exclusion reinforces fears of indiscriminate punishment among privileged-group members, regardless of rebel promises of pluralism and good treatment. Fears of indiscriminate punishment, in turn, spur actors in civil wars to comply with the side that can protect them from this violence. People who believe that they will likely be targeted by side A due to ascriptive characteristics will find little reason to cooperate with side A, and will instead comply with side B. After all, if they attempt to comply with side A, they might still suffer violence; at least by complying with side B they might enjoy the latter's protection. ${ }^{29}$ Fearing that rebels will victimize them whatever they do, some members of privileged groups may remain compliant with the regime to stay safe. This fear operates in spite of rebel attempts at reassurance, because rebels might be seeking to obtain their acquiescence before reneging.

In short, a crucial and underexplored effect of regime ethnic exclusion is to undermine the credibility of the non-ethnic character of rebel agendas. Even if rebel groups adopt a pluralist agenda to try to promise good treatment to privileged-group members, a history of ethnic mobilization, the salience of an ethnic frame (reinforced by regime leaders), and the clear potential for the return of such an agenda will often spur mistrust of any rebels among privileged-group members. They will therefore tend to be more compliant with the regime, and less inclined to defect, surrender or cooperate with rebels.

In turn, privileged-group compliance reduces the likelihood that a conflict will end. As the above analysis demonstrates, this is a commitment problem: rebels cannot credibly commit to

\footnotetext{
${ }^{29}$ Kalyvas, Logic of Violence, 143-45.
} 
pluralism and to non-discrimination against privileged-group members. The result is longer civil wars. Unlike the standard unitary commitment problem, ${ }^{30}$ in which Side A fears to surrender or negotiate because Side B may not keep its promises once Side A has lain down its arms, this followers' commitment problem assumes that followers' interests may often diverge from those of their leaders or their armed groups. Opposition groups, above all, win civil conflicts by inducing rank-and-file combatants and civilians on the other side to surrender and defect. ${ }^{31}$ But if followers and civilians cannot be reassured that they can safely surrender, defect or cooperate, civil war termination is harder.

Some qualifiers are in order. First, a highly exclusive regime might exclude many different identity groups, and holding a coalition of such groups together might well require credible non-ethnic claims. In contrast, regimes that exclude a single large ethnic category might strengthen the loyalty trap further. A rebel group's non-ethnic claims would typically be less credible here, for there is likely to be a history of mobilization and strong incentives to renege on pluralism and mobilize this excluded group. In turn, mobilizing a large group along identity lines may ultimately pose a particularly fearsome threat to members of a small in-group. ${ }^{32}$ Hence, a diverse excluded population may mitigate the result here somewhat.

Second, this theoretical approach stresses that regime exclusion by itself can prompt compliance and long civil wars, in spite of rebels' non-ethnic claims. The scope for the approach's key contribution, therefore, is to be found in the context of rebellions that do not propound ethnic agendas. Moreover, it is not clear that how exclusive a regime is should make a difference to civil war duration when rebels mobilize excluded ethnic groups. After all, the

\footnotetext{
${ }^{30}$ Fearon, "Rationalist Explanations for War"; Walter, "Critical Barrier"; Fearon, "Why Do Some Civil Wars."

${ }^{31}$ Russell, Rebellion, Revolution, and Armed Force; Erica Chenoweth and Maria J. Stephan, Why Civil Resistance Works: The Strategic Logic of Nonviolent Conflict (New York: Columbia University Press, 2011).

${ }^{32} \mathrm{I}$ thank an anonymous reviewer for drawing my attention to this threat.
} 
commitment problem can apply on the rebel side; once launched, it is difficult for rebels to lay down their arms, fearing identity-based reprisals. ${ }^{33}$ Rebels claiming to represent proportionately small and geographically isolated ethnic groups have spurred very long civil conflicts (say, rebellions in southern Thailand or Mindanao in the southern Philippines). It may therefore not take a highly exclusive regime to spur a long-running insurgency along ethnic lines. The argument may be more relevant to civil conflicts over government than over territory, but given that privileged-group members are often present in territory claimed by rebels, it is relevant to territorial conflicts too.

Finally, it is worth asking to what extent the thesis only applies to ethnic exclusion. To be sure, other things besides communal identity can also furnish markers of loyalty, such as class identity or political affiliation. ${ }^{34}$ Ethnic identity may be especially common in identifying loyalties in the medium term because it is comparatively difficult to change, based as it is upon "attributes associated with, or believed to be associated with, descent." ${ }^{, 35}$ But in the short time scale involved in civil war, other markers might be used too. Hence, I do not argue that my approach only applies to ethnic identity. This article focuses on ethnic exclusion, then, largely because identity divisions seem to be relatively frequently used as bases of political exclusion and of identifying loyalties. ${ }^{36}$ Communal divisions have political currency in many different settings, providing a point of reference and permitting large-scale comparisons.

Several kinds of evidence are relevant for this approach. At a micro level, members of a privileged minority in a highly exclusive regime should believe themselves locked into loyalty in

${ }^{33}$ Fearon, "Why Do Some Civil Wars."

${ }^{34}$ Kalyvas, "Ethnic Defection," 1047.

${ }_{35}^{35}$ Chandra, "What Is Ethnic Identity and Does It Matter?," 398.

${ }^{36}$ Cynthia H Enloe, Ethnic Soldiers: State Security in Divided Societies (Athens, GA: University of Georgia Press, 1980); Elaine K. Denny and Barbara F. Walter, "Ethnicity and Civil War," Journal of Peace Research 51, no. 2 (2014): 199-212. 
the face of an armed rebellion. In particular, even members of the supposedly privileged in-group who do not much materially benefit from the regime should have this belief - in contrast to an approach based on concentrated benefits under exclusive regimes. ${ }^{37}$ It should also be clear that privileged-group members see a rebel group's claims to a non-ethnic agenda as non-credible, and are fearful of categorical violence despite such claims. And it should be clear that this feeds their decisions not to comply with the rebels. In the next section, I demonstrate how the argument applies to the Syrian case in 2011-2012. While space does not permit comparative case studies, the Syrian case represents an extreme-value case: an initially non-ethnic rebellion (the Free Syrian Army) in the face of an extremely exclusive regime with an excluded population dominated numerically by Sunni Arabs. This case therefore suggests the plausibility of the argument in an environment conducive to finding evidence for it. I therefore complement this analysis with a large-scale statistical test.

At a macro level, comparative and statistical studies have already found evidence for one key step in the argument, that ethnically exclusive regimes face relatively little defection from privileged-group members. This finding emerges in studies both of defection in the face of uprisings from below ${ }^{38}$ and of military coups. ${ }^{39}$ In addition to loyalty and defection patterns, however, we should find at a macro level that, with a non-ethnic rebellion, the more exclusive the regime, the longer the civil war. I test this novel implication in the second empirical section.

\footnotetext{
${ }^{37}$ Heger and Salehyan, "Ruthless Rulers."

38 Theodore McLauchlin, "Loyalty Strategies and Military Defection in Rebellion," Comparative Politics 42, no. 3 (2010): 333-50; Sharon Erickson Nepstad, "Mutiny and Nonviolence in the Arab Spring: Exploring Military Defections and Loyalty in Egypt, Bahrain, and Syria," Journal of Peace Research 50, no. 3 (2013): 337-49; Julien Morency-Laflamme, "A Question of Trust: Military Defection during Regime Crises in Benin and Togo" (manuscript, Montreal, September 21, 2016).

${ }^{39}$ Philip G. Roessler, "The Enemy Within: Personal Rule, Coups, and Civil Wars in Africa," World Politics 63, no. 2 (2011): 300-346; Kristen A. Harkness, "The Ethnic Army and the State Explaining Coup Traps and the Difficulties of Democratization in Africa," Journal of Conflict Resolution 60, no. 4 (2016): 587-616.
} 


\section{A theory-building case: Syria's Alawites}

The Syrian civil war, ongoing since 2011, illustrates the central theoretical dynamics I outline above, and indeed spurred their development. Some members of the Alawite Arab minority dominate executive power in the Syrian regime. While the regime certainly includes non-Alawites, there is clear and significant underrepresentation of other categories (the Sunni Arab majority, Christian and Druze Arabs, and Kurds) in the regime. In turn, identity frames are salient for Alawites. Hence, a fear of being targeted by the opposition regardless of their behavior, a fear manipulated and magnified by specific regime strategies, helps keep Alawites compliant. In recounting the Syrian case, I do not differ from the widely held scholarly view that, despite considerable power inequalities among Alawites, they often support the regime out of fear of the opposition. ${ }^{40}$ As I argue below, though, there are crucial differences between this account and the popular conventional wisdom: above all, the analysis does not mean that behavior flows directly from identity.

Syria's regime pursues a high degree of exclusion along identity lines; in turn, as the loyalty trap expects, opposition has often mobilized excluded categories too. Alawites, a religious minority usually held to be about $12 \%$ of the population of Syria, dominate the military establishment and have done since the late 1970s. Constituting a large majority of noncommissioned officers by the mid-1950s, Alawites came to dominate the officer corps as factionalism among Sunni officers led to successive coups and purges from the late 1940s

\footnotetext{
${ }^{40}$ Hanna Batatu, "Some Observations on the Social Roots of Syria's Ruling, Military Group and the Causes for Its Dominance," Middle East Journal 35, no. 3 (1981): 336; Aziz Nakkash, "The Alawite Dilemma in Homs: Survival, Solidarity and the Making of a Community" (Berlin: Friedrich Ebert Siftung, March 2013); Bruno Paoli, "Et maintenant, on va où? Les alaouites à la croisée des destins," in Pas de printemps pour la Syrie: les clés pour comprendre les acteurs et les défis de la crise (2011-2013), ed. François Burgat and Bruno Paoli (Paris: La Découverte, 2013), 138; Christopher Phillips, "Sectarianism and Conflict in Syria," Third World Quarterly 36, no. 2 (2015): 369; Leon T. Goldsmith, Cycle of Fear: Syria's Alawites in War and Peace (London: Hurst, 2015).
} 
through the 1960s. ${ }^{41}$ Pronouncing an official Ba'thist doctrine of secular, socialist Arab nationalism, the regime of Hafiz al-Assad (1970-2000) increasingly relied upon a core of Alawites, and in particular those with family connections to the president himself. ${ }^{42}$ The regime narrowed its base especially after the 1976-82 uprising of the Sunni Muslim Brotherhood and the regime's brutal response. Brotherhood claims that Alawites were heretics, and the massacre of dozens of mainly Alawite military cadets in Aleppo in 1979, fed Alawite fears of the Brotherhood and of Sunni sectarian politics. ${ }^{43}$ Assad entrusted Alawite-dominated military units with the repression of the Brotherhood. It was these units, most notably, that killed tens of thousands in the destruction of the city of Hama in 1982 and thereby ended the uprising. ${ }^{44}$ The reliance on Alawites continued and heightened after the uprising. According to Batatu, Alawites held two of five divisional commands in 1973, and seven of nine by $1992 .{ }^{45}$ Hafiz's son Bashar al-Assad, in power since Hafiz's death in 2000, further narrowed the regime (for example ousting the most prominent Sunni senior officer in 2005) and became more dependent on familial ties in crony capitalism. ${ }^{46}$

Although Alawites dominate the military elite, there is hardly a perfect correlation between being Alawite and receiving state privilege, or being Sunni and not. Regime members' state-business networks frequently include Sunni businesspeople, though more in individualized

\footnotetext{
${ }^{41}$ Batatu, "Some Observations on the Social Roots of Syria's Ruling, Military Group and the Causes for Its Dominance," 341-43.

${ }^{42}$ Nikolaos Van Dam, The Struggle for Power in Syria: Politics and Society under Asad and the Ba'th Party, 4th ed. (London: Tauris, 2011).

${ }^{43}$ Paoli, "Et maintenant, on va où?," 133-34.

${ }^{44}$ Van Dam, The Struggle for Power in Syria, 114-15.

${ }^{45}$ Hanna Batatu, Syria's Peasantry, the Descendants of Its Lesser Rural Notables, and Their Politics (Princeton: Princeton University Press, 1999), 227-28.

${ }^{46}$ Raymond Hinnebusch, "Syria: From 'Authoritarian Upgrading' to Revolution?," International Affairs 88, no. 1 (2012): 99; Phillips, "Sectarianism and Conflict in Syria," 365.
} 
network relationships than through incorporating the Sunni business class as a group. ${ }^{47}$ Further, despite Ba'thist rural development policies, many Alawites have remained economically disadvantaged. ${ }^{48}$ However, at a broader scale than just the military elite, it does appear that Alawites systematically enjoyed greater access to government employment than average. ${ }^{49}$

As the loyalty trap expects, however, exclusion policies have hidden intra-sectarian differences by identifying Alawites as loyalists. Alawites are supposedly identifiable by their family names, places of origin, and pronunciation in Arabic. ${ }^{50}$ A joke about the regime demonstrates the public's equation of the regime with Alawites, saying that in Assad's palace, "even the phones ring in "Alawi dialect." 51 In turn, people arrested by state security have sometimes tried to fake an Alawite accent. ${ }^{52}$ This labelling elides social and political differences among Alawites. Alawites in central cities, for example Homs, often argue that the real power among Alawites is in coastal settlements, such as Qardaha (Hafiz al-Assad's town of origin). But they also recount their Sunni neighbors' belief that, as Alawites, they have special advantages. ${ }^{53}$

Despite the dominance of narrowly sectarian Sunni groups the last few years of the Syrian civil war, the beginning of the war illustrates that rebels in ethnically exclusive regimes sometimes attempt to push non-ethnic agendas. It therefore also helps illustrate whether they can be successful in doing so. When demonstrations began in March 2011, opposition activists attempted consciously to push back against sectarian narratives, specifically trying to reassure

\footnotetext{
${ }^{47}$ Bassam Haddad, Business Networks in Syria: The Political Economy of Authoritarian Resilience (Stanford: Stanford University Press, 2012), 38.

${ }^{48}$ Paoli, "Et maintenant, on va où?," 128-29; Batatu, Syria's Peasantry, 227-30.

${ }^{49}$ Kevin Mazur, "Sectarianism, Violence and the State in Contentious Processes: Evidence from the Syrian Uprising” (Annual Conference of the Project on Middle East Political Science, Washington, DC, May 22, 2015 ), 19.

${ }^{50}$ Goldsmith, Cycle of Fear, 117.

${ }^{51}$ Lisa Wedeen, Ambiguities of Domination: Politics, Rhetoric, and Symbols in Contemporary Syria (Chicago: University of Chicago Press, 1999), 128.

${ }_{52}$ Goldsmith, Cycle of Fear, 140.

${ }^{53}$ Nakkash, "Alawite Dilemma," 13-14.
} 
Alawites that they would not be harmed. ${ }^{54}$ Opposition slogans included "Not Sunni and not Alawi, we want freedom." 55 Activists organized meetings among leaders of different communities, for example in Jableh and in Homs, to combat possibly regime-planted rumors of sectarian violence. ${ }^{56}$ Though demonstrations were concentrated in Sunni communities according to Mazur's event-count data, ${ }^{57}$ demonstrators were far from exclusively Sunni. Some Alawis took prominent roles. ${ }^{58}$ After the descent into civil war, the leadership of the opposition in the Syrian National Council and its affiliated rebel army, the Free Syrian Army, have called above all for the removal of Assad and the establishment of a democratic regime, not identity-based appeals.

The regime's master narrative about the demonstrations, in contrast, was that they were narrowly sectarian. According to regime propaganda, the opposition would promote Sunni Islamist extremism. ${ }^{59}$ As demonstrations rolled across Tunisia in late 2010 and early 2011, but before the outbreak of large-scale protest in Syria, word descended the military chain of command to prepare to face attack from Islamist radical groups. ${ }^{60}$ This extremism, according to the regime, would threaten Syria's religious minorities and secular Sunnis alike. Indeed, it is notable that the regime did not tend to mobilize Alawites through narrowly pro-Alawite rhetoric, instead stressing its Syrian nationalism so as not to alienate its non-Alawite supporters. ${ }^{61}$

\footnotetext{
${ }^{54}$ Salwa Ismail, "The Syrian Uprising: Imagining and Performing the Nation," Studies in Ethnicity and Nationalism 11, no. 3 (2011): 540; Sadek Abdulrahman, "The Lost Cries of Alawites," The Syrian Observer, September 30, 2014.

${ }^{55}$ Ismail, "The Syrian Uprising," 543.

56 Ibid.

${ }^{57}$ Mazur, "Sectarianism, Violence and the State," 31.

${ }^{58}$ Paoli, "Et maintenant, on va où?," 135.

${ }^{59}$ Philippe Droz-Vincent, "'State of Barbary' (Take Two): From the Arab Spring to the Return of Violence in Syria," The Middle East Journal 68, no. 1 (2014): 46-47.

${ }^{60}$ Nakkash, "Alawite Dilemma," 3.

${ }^{61}$ Ismail, "The Syrian Uprising," 541-42.
} 
Underneath its official propaganda, however, the regime targeted Alawite communities with efforts to heighten fears not only of Islamism but of Sunnis generally. In doing so, the regime played on and reinforced the existing identity frame for understanding violence, illustrating the limits of rebel attempts to propound non-ethnic agendas. Regime agents distributed sandbags in some Alawite villages, telling residents to prepare to be attacked by Sunnis. ${ }^{62}$ The regime seems especially to have manipulated the fears of residents of the new, mainly Alawite suburbs of cities like Damascus and Homs. ${ }^{63}$ One resident of such a community reported that government agents distributed automatic weapons in his neighbourhood. ${ }^{64}$ As Phillips argues, the regime's narrative of Sunni Islamism and rumors of sectarian violence had a receptive audience. ${ }^{65}$ Many were ready to take the automatic weapons that the regime distributed: “They told us, "The Sunnis are going to kill you”...They scared us. Of course some people in our community are narrow-minded; they believed them and, unfortunately, many people accepted the weapons." ${ }^{\prime 66}$

Hence, Alawites' receptiveness to rumors of identity-based mobilization and targeting emerged from long-standing regime exclusion policies, not just from rebel behavior. It must be noted, though, that endogenous conflict dynamics subsequently reinforced Alawite fear. The regime's utterly brutal response to largely nonviolent demonstrations helped to encourage the opposition to take up arms, in turn heightening Alawite fears of a spiral into reprisal killing. ${ }^{67}$ Members of the opposition, including members of the "mainstream" opposition, also began to

\footnotetext{
${ }^{62}$ Phillips, "Sectarianism and Conflict in Syria," 369.

${ }^{63}$ Droz-Vincent, "'State of Barbary' (Take Two)," 42; Nakkash, "Alawite Dilemma."

${ }^{64}$ Neil MacFarquhar, "Assad's Response to Syria Unrest Leaves His Own Sect Divided," New York Times, June 9, 2012, http://www.nytimes.com/2012/06/10/world/middleeast/syrian-alawites-divided-by-assads-response-tounrest.html?_r=0.

${ }^{65}$ Phillips, "Sectarianism and Conflict in Syria," 360.

${ }^{66}$ MacFarquhar, "Assad's Response."

${ }^{67}$ Benedetta Berti and Jonathan Paris, "Beyond Sectarianism: Geopolitics, Fragmentation, and the Syrian Civil War," Strategic Assessment 16, no. 4 (2014): 24.
} 
deploy more sectarian slogans and actions that lumped Alawites together. One opposition activist said, "Every Alawite between the age of 16 to 40 is a murderer, whether he likes it or not."68 New slogans included "We didn't used to hate the Alawis, now we do." ${ }^{\text {" }}$ Prominent opposition figures were recorded saying that Alawites would be "exterminated."70 Indeed, the regime may have encouraged opposition sectarianism directly. In May and June 2011, it released numerous imprisoned jihadists, claiming an attempt at conciliation. Opposition activists and ex-prisoners themselves argue that the regime fully intended that the released prisoners would take up arms. ${ }^{71}$

Thus over the course of 2012 and 2013, more explicitly sectarian and extremist rebel groups like the Nusra Front and the Islamic State of Iraq and Syria (ISIS) gained prominence in the war, overtaking the Syrian National Council and the Free Syrian Army. ${ }^{72}$ Such groups explicitly called for, and deployed, horrific violence against civilians, ${ }^{73}$ sometimes identifying religious minorities as enemies to be killed and recording videos of horrors they perpetrated. ${ }^{74}$ From this point on, it becomes somewhat more difficult to see whether the regime's exclusion or the sectarian rebellions did more to reinforce Alawite fears. But for 2011 and much of 2012, I argue that existing regime exclusion policies and short-run manipulations did much to promote these fears, undermining the rebels' attempts to reassure Alawites through an officially nonsectarian agenda.

\footnotetext{
${ }^{68}$ Mariam Karouny, “Against Syrian Anger, Assad's Sect Feels Fear,” Reuters, February 1, 2012, http://www.reuters.com/article/2012/02/01/us-syria-alawites-idUSTRE81024G20120201.

${ }^{69}$ Christopher Phillips, "Syria's Torment," Survival 54, no. 4 (2012): 76.

${ }^{70}$ Paoli, "Et maintenant, on va où?," 136; Karouny, "Against Syrian Anger."

${ }^{71}$ Rania Abouzeid, “The Jihad Next Door,” Politico, June 23, 2014, http://www.politico.com/magazine/story/2014/06/al-qaeda-iraq-syria-108214.html\#ixzz35Y4Y7ulm.

72 International Crisis Group, "Syria’s Metastasising Conflicts,” Middle East Report (Brussels: International Crisis Group, June 27, 2013).

${ }^{73}$ Lama Fakih, "You Can Still See Their Blood”: Executions, Indiscriminate Shootings, and Hostage Taking by Opposition Forces in Latakia Countryside (New York: Human Rights Watch, 2013).

${ }^{74}$ Droz-Vincent, "'State of Barbary' (Take Two)," 56.
} 
In this environment of fear, Alawites largely remained compliant with the regime. Most notably, relatively few Alawites in the security services defected. This is despite the estimated 10-25,000 defectors, from a 200,000-strong military, that have formed the backbone of the Free Syrian Army. ${ }^{75}$ Sunnis, who had formed most of the rank and file of the regime's forces, were the large majority of defectors. ${ }^{76}$ Outside of the formal military, Alawites have provided an important manpower reserve in militias, ${ }^{77}$ though Sunnis have joined as well. ${ }^{78}$

It is clear that this compliance rests to a great degree on fear of the opposition. Even some Alawites sympathetic with the opposition found themselves believing they did not have a place in the opposition and that the regime's preservation was an existential issue. ${ }^{79}$ Indeed, many Alawites appeared to believe that, even if they attempted to cooperate with the rebels, the latter would still target them. While some Alawites reported being welcomed into the opposition at first, there was clearly suspicion in opposition circles. One opposition activist in Damascus said the opposition would suspect that Alawites in their ranks were spies, and one of his Alawite acquaintances in the opposition revealed his sect to few. ${ }^{80}$ Wajdy Mustafa, an exiled Alawite activist, reports that opposition sympathizers among Alawites often "fear seeking haven among the Sunnis, too, lest they be killed for their sect." ${ }^{\prime 81}$

${ }^{75}$ Hinnebusch, "Syria," 110; Phillips, "Syria's Torment," 76.

${ }^{76}$ Holger Albrecht, "Does Coup-Proofing Work? Political-Military Relations in Authoritarian Regimes amid the Arab Uprisings," Mediterranean Politics 20, no. 1 (2015): 36-54; Hicham Bou Nassif, “'Second-Class': The Grievances of Sunni Officers in the Syrian Armed Forces," Journal of Strategic Studies 38, no. 5 (2015): 626-49; Kevin Koehler, Dorothy Ohl, and Holger Albrecht, "From Disaffection to Defection: How Networks Facilitate Military Insubordination in Civil Conflict," Comparative Politics 48, no. 4 (2016): 439-57.

${ }^{77}$ Hinnebusch, "Syria," 108.

${ }^{78}$ Droz-Vincent, “'State of Barbary” (Take Two)," 54.

${ }^{79}$ Paoli, "Et maintenant, on va où?," 137-38.

${ }^{80}$ Nir Rosen, "Syria's Alawite Activists Stuck in the Middle," Al-Jazeera, March 8, 2012, http://www.aljazeera.com/indepth/features/2012/03/201237101424192726.html.

${ }^{81}$ MacFarquhar, “Assad's Response." 
This compliance among Alawites has extended well beyond those who benefited directly from the regime. For example, despite a sense among Alawites from Homs that they do not enjoy the privileges of Alawites from the coast, the belief that Sunnis see them as privileged has apparently helped to reinforce their willingness to fight. ${ }^{82}$ Anecdotes indeed abound of Alawites who have very little good to say about the Assad regime but will continue to fight for it out of fear. ${ }^{83}$ According to Abu Khader (a nickname), a member of the Republican Guard, Assad is a "thief" who "got us into this war to keep his authority. But as Alawites, we are forced to fight, because the opposition is all Sunnis, and they want to kill us all." ${ }^{84}$ Thus the rebels are all interpreted in a sectarian frame, whether they make sectarian claims or not. In other words, privileging members of a minority group affects their loyalties not only because it concentrates benefits in fewer hands, but also because it identifies as loyalists even those who get very little from the regime. ${ }^{85}$

As the war has dragged on and Alawite sacrifices have increased, their resentment of the regime has grown as well. Correspondingly, there are increasing reports of acts of resistance, like roadblocks against military recruiters, in Alawite communities. ${ }^{86}$ Alawite willingness to fight may therefore not last. But it has lasted thus far.

At the beginning of the Syrian conflict, then, the principal umbrella rebel group attempted to emphasize a non-ethnic agenda, focusing on removing the Assad regime, with hopes that doing so would reassure Alawites. I argue, however, that the regime's exclusion, and the

\footnotetext{
${ }^{82}$ Nakkash, "Alawite Dilemma."

${ }^{83}$ Aryn Baker, "Syria's Minority Alawites Cling to Assad, Hope for Peace," Time, October 24, 2013; Joshua Hersh, “The Dilemma of Syria's Alawites," The New Yorker - News Desk, October 18, 2013, http://www.newyorker.com/news/news-desk/the-dilemma-of-syrias-alawites.

${ }^{84}$ Baker, "Syria's Minority Alawites."

${ }^{85}$ This point was well made by [REFERENCE DELETED FOR ANONYMITY]

${ }^{86}$ Ruth Sherlock, "In Syria's War, Alawites Pay Heavy Price for Loyalty to Bashar Al-Assad," The Telegraph, April 7, 2015.
} 
resulting history of sectarian mobilization and opportunities for manipulation, facilitated an identity frame for understanding the conflict and its violence. This stoked Alawites' fears, keeping them compliant. As sectarian rebel groups came to the fore, the direct contribution of the regime's exclusion on Alawites' compliance and civil war duration is harder to gauge, but it is noteworthy that the result has often been to elide differences between sectarian and non-sectarian rebels. Many Alawites seem unwilling to believe that non-sectarian opposition claims could be credible.

Several qualifications are in order. First, given the importance of international support from Hizbullah, Iran and Russia in defending the regime, and the fact that the regime's own security forces are far from exclusively Alawite, one cannot necessarily conclude that Alawite combatants have been, strictly speaking, sufficient to keep the regime in power. But it is clear that they have considerably assisted the regime's war effort.

Second, many Alawites might not be "really" fearful of the opposition, but may believe they have to follow and perpetuate the regime's narrative of the conflict. Lisa Wedeen emphasizes the importance, under the Assad regime, of figuring out what the regime wants one to do and doing it. That is, Syrians often act "as if" the regime's narratives were true, and in doing so, help to constitute the regime's power. ${ }^{87}$ In the case of sectarian views of the conflict in 2011, claims that the opposition would target Alawites may have worked in a similar way: Alawites may have repeated them whether they believed them or not, constructing a narrative of sectarian conflict that governed Alawite behavior, and constructing dissidents as traitors to the

\footnotetext{
${ }^{87}$ Wedeen, Ambiguities of Domination, 46, 145-47.
} 
Alawites as well as to Syria. Indeed, some Alawites do appear to have enforced group norms of compliance, targeting other Alawites who criticize the regime. ${ }^{88}$

My account differs from popular understandings of the Syrian civil war as a "sectarian conflict," where everyone's loyalties are easily read off of their identities. First, I make no claim about any actors other than Alawites. The brutal fighting in the crucial city of Aleppo, for example, cuts across the Sunni community ${ }^{89}$ Relatedly, it is essential not to read into my account the idea that Alawites support Assad purely out of identity solidarity with a largely Alawite elite. ${ }^{90}$ Indeed, as noted, frustration and anger at the regime appear fairly common among Alawites. My argument, indeed, is that despite this resentment, Alawites are heavily dissuaded from cooperating with rebels. The construction of Alawites as privileged, and of Sunnis as disenfranchised and harboring grievances, sustained the fear of Sunni mobilization and categorical violence, even in the early days when the officially non-sectarian opposition was in the ascendant.

\section{Cross-national hypothesis-testing}

In the Syrian case, the loyalty trap seems powerful in reducing the credibility of rebel attempts to portray themselves as non-ethnic and thereby reassure privileged-group members. Does this mechanism help explain the duration of civil conflict more widely? Wucherpfennig and colleagues provide important recent research that focuses on rebel ethnic claims in the context of regime ethnic exclusion, arguing that rebel groups that mobilize excluded ethnic groups are able to sustain their efforts over longer periods of time. They find that civil conflicts

\footnotetext{
${ }^{88}$ MacFarquhar, "Assad's Response."

${ }^{89}$ Phillips, "Sectarianism and Conflict in Syria," 361.

90 Nakkash, "Alawite Dilemma," 1.
} 
involving such groups tend to last longer than civil conflicts where rebels claim to represent politically included ethnic groups or make no such ethnic claims. They argue that this is in part because exclusive regimes raise in-group members' fears of revenge. ${ }^{91}$ But, by focusing on ethnic mobilization by the rebel group as the key way that commitment problems get activated, they leave unexplored one important implication of the commitment-problem logic, which I investigate here: that rebel claims to pluralism are less credible when regimes are more exclusive. Hence even when rebel groups do not make ethnic claims, the exclusiveness of the regime should undermine their pluralist discourse, reinforce privileged-group loyalty, and produce longer civil conflicts.

I use data from Wucherpfennig and colleagues on the duration of civil conflict. ${ }^{92}$ These data are based on the UCDP Dyadic Armed Conflict Dataset, ${ }^{93}$ covering 375 conflict dyads in the period 1946-2005. To generate indicators of overall regime ethnic exclusiveness, I linked this dataset with the Ethnic Power Relations (EPR) version 3 data on the ethnic composition of access to executive power at the outset of each rebellion. ${ }^{94}$ Wucherpfennig and colleagues introduce the ACD2EPR data linking rebel organizations to politically included and excluded ethnic groups. ${ }^{95}$ A rebel organization is considered linked to an ethnic group if both (a) recruits mainly among and (b) claims to represent that ethnic group. The appropriate frame for my analysis is the 179 rebel groups that are not linked to any ethnic group. ${ }^{96}$ This is because the key

\footnotetext{
${ }^{91}$ Wucherpfennig et al., "Ethnicity, the State," 86.

${ }^{92}$ Wucherpfennig et al., "Ethnicity, the State."

${ }^{93}$ Lotta Harbom, Erik Melander, and Peter Wallensteen, "Dyadic Dimensions of Armed Conflict, 1946-2007," Journal of Peace Research 45, no. 5 (2008): 697-710.

${ }^{94}$ Wimmer, Cederman, and Min, "Ethnic Politics and Armed Conflict."

${ }^{95}$ I recoded some borderline cases as excluded-group rebellions to ensure the results were not being driven by cases erroneously coded as nonethnic. The recoding decisions are available in the web appendix.

${ }^{96}$ The latest edition of ACD2EPR codes a single Syrian rebel group, "Syrian insurgents," as linked to the Sunni Arab population. As I argue above, though, one must distinguish the FSA umbrella, whose leadership attempted at least to put forward a non-sectarian agenda, from more sectarian rebels.
} 
implication of the loyalty trap is that exclusive regimes make it hard for rebels to credibly present themselves as non-ethnic. When rebels make ethnic claims, it is plausible that these claims by themselves undermine privileged-group members' trust in rebels, and that the regime's degree of ethnic exclusion would not make much difference on top of this. Moreover, when rebels make ethnic claims, it is frequently on behalf of small excluded groups to whom even a regime including a large majority cannot make credible commitments, with the consequence that civil wars tend to be lengthy. ${ }^{97}$ Hence there is not much reason to suppose that the degree of regime exclusion should have a clear effect on civil conflict duration with excluded-group rebellions. I also use a model with both excluded-group and non-ethnic rebellions, interacting rebel agendas with the regime's ethnic exclusiveness, in order to test to what extent exclusiveness undermines the war-shortening effect of non-ethnic conflicts that Wucherpfennig and colleagues find. ${ }^{98}$

To conceptualize and measure the major independent variable, the exclusiveness of a regime, I examine the share of the population broken down by access to political power according to the EPR dataset. Following EPR, an ethnic category may be privileged in access to power (included), systematically excluded, or simply irrelevant to politics (neither privileged, nor discriminated against, nor mobilized in politics). I expect that, in civil conflicts in which rebels do not make ethnic claims, the larger the excluded share, the longer the civil conflict. Civil war duration should, in contrast, be decreasing in both included and irrelevant shares-the former because a larger included share may be likely to produce internal divisions that rebels can

\footnotetext{
97 Fearon, "Why Do Some Civil Wars."

${ }^{98}$ Included-group rebellions, which Wucherpfennig et al also code, are not relevant here and are omitted from all the analyses.
} 
exploit if they can make cross-ethnic appeals; the latter because it indicates that for a more substantial share of the population, ethnicity is just not as salient.

However, a countervailing tendency may weaken the relationship between size of excluded population and civil war duration. A larger excluded population may mean many excluded groups; in turn, this diversity may make non-ethnic claims among rebels more credible, since rebel leaders have to make appeals across ethnic lines. ${ }^{99}$ In contrast, with a single large excluded group (as with Sunnis in Syria) the fear that the rebellion will eventually act along identity lines and will threaten the incumbent minority might be especially strong.

Hence:

H1. In civil conflict dyads in which the rebel organization does not claim to represent an ethnic group, the larger and more concentrated the share of the population belonging to politically excluded ethnic categories, the longer the civil conflict.

I measure exclusion and the concentration of the excluded population together, in two ways. First, I include the share of the population belonging to politically excluded ethnic categories and control for the number of excluded categories, since a larger share excluded should naturally correlate with more excluded groups ( $r=.264$ in my dataset). Second, I use share of the population belonging to the largest excluded category, capturing both exclusion and the concentration of the excluded population in a single metric.

Table 1 lists the frequency of types of rebel organization by the share of the population excluded from power, to show where the data are. As one might expect, there is a clear trend for more excluded-group rebellions, and fewer included-group rebellions, in more exclusive regimes

\footnotetext{
${ }^{99}$ Alternatively, it may indicate the potential for many excluded-group rebellions, suggesting that the regime should stand firm against any rebellion to improve its bargaining position. Barbara F. Walter, Reputation and Civil War: Why Separatist Conflicts Are So Violent (Cambridge: Cambridge University Press, 2009).
} 
(chi-square $=32.31, p<.001)$. But, notably, there are plenty of rebel organizations that do not make ethnic claims even in exclusive regimes, making my hypothesis empirically important.

Table 1. Frequency of rebellions by exclusiveness and ethnic link of rebellion

\begin{tabular}{lll}
\hline $\begin{array}{l}\text { Quartile of regime } \\
\text { exclusiveness } \\
\begin{array}{l}\% \quad \text { excluded } \\
\text { ethnicity })\end{array}\end{array}$ & $\begin{array}{l}\text { Rebels do not make } \\
\text { ethnic claims }\end{array}$ & $\begin{array}{l}\text { Rebels linked to } \\
\text { excluded } \\
\text { group }\end{array}$ \\
\hline $1^{\text {st }}(<4.4 \%)$ & 60 & 13 \\
$2^{\text {nd }}(4.4 \%-18 \%)$ & 46 & 37 \\
$3^{\text {rd }}(18 \%-39.5 \%)$ & 35 & 49 \\
$4^{\text {th }}(\geq 39.5 \%)$ & 38 & 49 \\
\hline
\end{tabular}

I follow Wucherpfennig and colleagues ${ }^{100}$ in testing Cox proportional-hazard models ${ }^{101}$ and in stratifying by an indicator for wars that begin with coups d'état. The models use the Efron method for resolving ties and have standard errors clustered on the conflict (i.e. to capture the link in standard errors between episodes of the same conflict recurring through time). I display results in terms of Cox coefficients, that is, in terms of the change in the hazard rate associated with a unit change in the covariate. Negative coefficient estimates thus indicate a lower risk that a conflict ended in any given time period, and hence, longer conflicts.

I control for predictors of civil conflict duration that may be plausibly related to ethnic exclusion policies. These include democracy (hence I control for a Polity score of 6 or higher);

\footnotetext{
${ }^{100}$ Wucherpfennig et al., "Ethnicity, the State."

${ }^{101}$ I tested the proportional-hazards assumption for each model using Schoenfeld residuals, and uncovered no reason to suppose it did not hold.
} 
Table 2. Cox proportional hazard estimates

\begin{tabular}{|c|c|c|c|c|c|}
\hline VARIABLES & $\begin{array}{l}\text { (1) } \\
\text { Non-ethnic } \\
\text { rebellions }\end{array}$ & $\begin{array}{l}\text { (2) } \\
\text { Non-ethnic } \\
\text { rebellions }\end{array}$ & $\begin{array}{l}\text { (3) } \\
\text { Non-ethnic } \\
\text { rebellions }\end{array}$ & $\begin{array}{l}4) \\
\text { Non-ethnic } \\
\text { rebellions }\end{array}$ & $\begin{array}{l}\text { (5) } \\
\text { Non-ethnic and excluded- } \\
\text { group rebellions }\end{array}$ \\
\hline Excluded share & $\begin{array}{l}-0.954 * * \\
{[0.424]}\end{array}$ & & & & \\
\hline Number of excluded ethnic groups & $\begin{array}{l}0.049 * \\
{[0.027]}\end{array}$ & & & & \\
\hline Size of largest excluded group & & $\begin{array}{l}-1.220 * * \\
{[0.582]}\end{array}$ & $\begin{array}{l}-0.890 \\
{[0.551]}\end{array}$ & $\begin{array}{l}-0.712 \\
{[0.637]}\end{array}$ & $\begin{array}{l}-0.659 \\
{[0.602]}\end{array}$ \\
\hline Excluded share $=0$ (dummy) & & & & $\begin{array}{l}0.482 * \\
{[0.253]}\end{array}$ & $\begin{array}{l}0.473 * \\
{[0.252]}\end{array}$ \\
\hline Rebels linked to excluded ethnic group & & & & & $\begin{array}{l}-0.173 \\
{[0.238]}\end{array}$ \\
\hline $\begin{array}{l}\text { Rebels linked to excluded ethnic group } \times \\
\text { size of largest excluded group }\end{array}$ & & & & & $\begin{array}{l}-0.032 \\
{[0.682]}\end{array}$ \\
\hline Territorial conflict & $\begin{array}{l}0.432 \\
{[0.297]}\end{array}$ & $\begin{array}{l}0.467 \\
{[0.324]}\end{array}$ & & $\begin{array}{l}0.503 \\
{[0.310]}\end{array}$ & $\begin{array}{l}0.015 \\
{[0.182]}\end{array}$ \\
\hline Rebels: territorial control & $\begin{array}{l}-0.346 \\
{[0.218]}\end{array}$ & $\begin{array}{l}-0.350 \\
{[0.218]}\end{array}$ & & $\begin{array}{l}-0.343 \\
{[0.209]}\end{array}$ & $\begin{array}{l}-0.276^{*} \\
{[0.153]}\end{array}$ \\
\hline Democracy & $\begin{array}{l}-0.827 * * * \\
{[0.269]}\end{array}$ & $\begin{array}{l}-0.799 * * * \\
{[0.264]}\end{array}$ & & $\begin{array}{l}-0.754 * * * \\
{[0.267]}\end{array}$ & $\begin{array}{l}-0.778 * * * \\
{[0.177]}\end{array}$ \\
\hline Observations & 927 & 927 & 927 & 927 & 2,175 \\
\hline
\end{tabular}

Robust standard errors in brackets

$* * * \mathrm{p}<0.01, * * \mathrm{p}<0.05, * \mathrm{p}<0.1$ 
rebel territorial control, since rebels may find safe haven among excluded groups; ${ }^{102}$ and whether the conflict is over territory rather than over a change in government.

Results appear in Table 2. The first four models are restricted to rebellions that do not make ethnic claims. The core hypothesis receives support in this analysis: civil conflicts do appear longer when more of the population is excluded from political power, particularly when that population is highly concentrated. In Model 1, I use the share of the excluded population and control for the number of excluded groups. The share excluded has a large substantive relationship to duration: a 25-percentage-point increase in exclusiveness is associated with a $21 \%$ lower likelihood of a conflict ending in any given period. Model 2 uses the size of the largest excluded group, a more parsimonious indicator. It shows even stronger effects: when the largest excluded group is 25 percentage points larger, civil conflicts are $28 \%$ less likely to end in any given period. These results suggest that even when rebels do not make ethnic claims, the regime's own exclusion practices are linked to longer civil wars.

However, two qualifications to this general portrait emerge from robustness checks in Models 3 and 4. In Model 3, I examine only the bivariate relationship between the size of the largest excluded group and civil conflict duration, and find that it is not statistically significant ( $p$ <.11). The same goes for the share of the population that is excluded (not shown here). Model 3 therefore suggests that the central result may be sensitive to model specification. However, I believe the control variables in Models 1 and 2 are necessary to correctly estimate the relationship between exclusion and civil war duration. Notably, democracies are likely to have less ethnic exclusion, but they also have much longer civil wars. Models 1 and 2 are preferable specifications.

\footnotetext{
${ }^{102}$ David E. Cunningham, Kristian Skrede Gleditsch, and Idean Salehyan, "It Takes Two: A Dyadic Analysis of Civil War Duration and Outcome," Journal of Conflict Resolution 53, no. 4 (2009): 570-97.
} 
It is possible that the key issue is simply whether a country experiences systematic exclusion at all, rather than the degree of exclusion. If true, then the loyalty trap would not fully explain the link between regime exclusivity and civil conflict duration in non-ethnic rebellions, since it emphasizes highly exclusive regimes. To check this, in Model 4, I include a dummy equalling 1 if share excluded equals zero and 0 otherwise. When this dummy is included, the coefficient on share excluded therefore estimates the relationship between an increase in exclusion and civil war duration, conditional on any exclusion occurring. This coefficient estimate remains negative, as expected. But it drops in magnitude and is no longer statistically significant. In contrast, the dummy for no ethnic exclusion has, as expected, a positive sign (meaning shorter civil conflicts) and is statistically significant. This suggests that there may be especially long civil conflicts in highly exclusive regimes, but I cannot conclude with confidence that they are longer than conflicts in only somewhat exclusive regimes. Some other mechanism may be at work to at least explain long civil conflicts in somewhat-exclusive regimes. An ethnic frame might be more easily activated even if only a small share of the population is ethnically excluded from power. Alternatively, a weak insurgent group without an overall ethnic agenda, seeking to fight an irregular war against an established state, may be better able to do so if it can make local alliances with excluded groups. It may only require a low threshold of exclusion to make such an alliance. In turn, irregular wars that such weak rebels tend to fight are especially long. ${ }^{103}$ However, the coefficient on the size of the largest excluded group is still substantial, so it is still possible that the loyalty trap travels to other highly exclusive regimes beyond Syria, lengthening their civil conflicts.

\footnotetext{
${ }^{103}$ Laia Balcells and Stathis N. Kalyvas, "Does Warfare Matter? Severity, Duration, and Outcomes of Civil Wars," Journal of Conflict Resolution 58, no. 8 (2014): 1390-1418.
} 
On balance, then, it thus appears that ethnic exclusion is associated with longer civil conflicts, even where rebels do not make ethnic claims. How substantively large is this effect, compared to the impact of rebel group characteristics? And how large are the substantive effects of the degree of exclusion, compared to the simple presence of exclusion? To examine this, I generate predicted median civil conflict durations at different degrees of regime exclusiveness and for rebellions linked to excluded groups and those that are not. First, in Model 5 I include the full array of civil conflicts (with rebels claiming to represent and recruiting among excluded and included ethnic groups, alongside non-ethnic rebel groups), and an interaction term between rebel group claims and the share of the excluded population. I also include the dummy for an excluded population of zero. Here, the coefficient on the largest excluded group gives the estimate for non-ethnic rebellions, and it essentially reproduces the finding from Model 4.

Table 3 then gives predicted median civil conflict durations on the basis of this model. In each case, categorical control variables are held at their modes. The pattern is striking. Regime ethnic exclusion appears to have substantive effects comparable to those of rebel agendas. The predicted median civil conflict is considerably longer in an extremely exclusive regime with nonethnic rebels than in a moderately exclusive regime $\left(25^{\text {th }}\right.$ percentile) with excluded-group rebels. At extremes of exclusion, non-ethnic rebellions experience may quite long civil conflicts. Further, though the gap in civil conflict length between no ethnic exclusion and moderate $\left(25^{\text {th }}\right.$ percentile) ethnic exclusion is large, the gap is larger still in magnitude between moderate and extreme $\left(95^{\text {th }}\right)$, although again I caution that the former is a statistically significant difference while the latter is not. This suggests that there may indeed be something particular to extremely exclusive regimes in the length of the civil conflicts they experience, and the loyalty trap provides a good explanation. 
Table 3. Predicted median civil war duration, days

\begin{tabular}{lll}
\hline $\begin{array}{l}\text { Percentile of regime } \\
\text { exclusiveness } \\
\text { (share of largest excluded group) }\end{array}$ & $\begin{array}{l}\text { Rebels do not make } \\
\text { ethnic claims }\end{array}$ & $\begin{array}{l}\text { Rebels linked to } \\
\text { excluded ethnic group }\end{array}$ \\
\hline $1^{\text {st }}(0 \%)$ & 364 & - \\
$25^{\text {th }}(3 \%)$ & 712 & 921 \\
$75^{\text {th }}(27 \%)$ & 883 & 1199 \\
$95^{\text {th }}(63 \%)$ & 1308 & 1673 \\
\hline
\end{tabular}

The web appendix includes more information. I include descriptive statistics and describe how I recoded some cases from ACD2EPR for the sake of a conservative estimate. I directly compare the results here to Wucherpfennig and colleagues' model to show the added value of including regime-side exclusiveness. I confirm empirically that it is important to compare the share excluded against the total population, including privileged and politically irrelevant ethnic categories. I demonstrate that the result here is not merely due to the presence of simultaneous ethnically-mobilized rebellions in ethnically exclusive regimes. I reanalyze my hypothesis using a different measure of exclusiveness, and while this analysis disconfirms the article's hypothesis, I provide an argument for why this article's measures are much more appropriate to my task. Finally, I conduct an exploratory analysis of the impact of exclusiveness on the outcome of civil conflicts, finding that exclusiveness in particular diminishes the likelihood of rebel victory (perhaps because in-group personnel stay loyal to the regime) and may also be associated with lower likelihood of government victory and negotiated settlements. 


\section{Conclusion}

The Syrian case therefore demonstrates that extreme exclusiveness can undermine the credibility of rebel claims to a non-ethnic agenda. The cross-national statistical analysis suggests, though not conclusively, that this mechanism may apply more broadly. This analysis has several important implications. First, it cautions against optimism about the duration of supposedly "non-ethnic" conflicts-i.e. those where rebels do not claim to be acting on behalf of an ethnic group. The depressing conclusion is that exclusive regimes can drive long civil conflicts, whatever the rebels' efforts to bypass these politics through a non-ethnic agenda. To the extent that the loyalty trap mechanism is in play, rebels cannot necessarily overcome their credible commitment problems just by making non-ethnic claims. The problem in such settings is on the side of the regime, whose members are essentially locked in to compliance. Rebellions against ethnically exclusive regimes might be well justified in principle. But even pluralist rebellions against such regimes generate long and bloody civil wars. Rebel groups may not make ethnic claims, but regime ethnic exclusivity makes claims on them.

More broadly, the argument here decouples ethnic conflict from ethnic grievance. It suggests that the category of "ethnic conflict" is only partially captured by the official claims of a rebel group. Rather, it appears as though regime members' response to rebel challenges can be affected by the degree of ethnic exclusion that prevails, even if ethnic grievances do not appear to be what the rebellion is "about," because they respond to social constructions of ethnic politics facilitated above all by the exclusiveness of the regime. Since the statistical analysis suggested that other mechanisms may be at work, particularly in less-exclusive regimes, further research should propose and assess these different mechanisms. For example, a minimal degree of ethnic 
exclusion may mean that identity operates as an important frame in at least a part of the population that is drawn in to civil conflict as a local ally.

Finally, the article suggests that civil wars should be longer when ordinary people are more willing to keep fighting and supporting one side. Scholars can therefore build on recent research on desertion and surrender ${ }^{104}$ to build hypotheses about civil war duration. It should be particularly relevant to focus on what keeps fighters from trusting that the other side will treat them well if they stand down. Research can thus usefully examine the impact on civil conflict duration of, for example, transparent legal norms that can govern amnesty, strong norms of discipline preventing violence against POWs and civilians, and massacres that occur after taking territory.

\footnotetext{
${ }^{104}$ Grauer, "Why Do Soldiers Give Up?"; Jason Lyall, "Why Armies Break: Explaining Mass Desertion in Conventional War" (Working paper, Yale University, New Haven, 2014); Kristine Eck, "Coercion in Rebel Recruitment," Security Studies 23, no. 2 (2014): 364-98; Theodore McLauchlin, "Desertion and Collective Action in Civil Wars," International Studies Quarterly 59, no. 4 (2015): 669-79; Ben Oppenheim et al., "True Believers, Deserters, and Traitors: Who Leaves Insurgent Groups and Why," Journal of Conflict Resolution 59, no. 5 (2015): 794-823; Koehler, Ohl, and Albrecht, "From Disaffection to Defection."
} 